\title{
Industry 4.0 and the digital society: concepts, dimensions and envisioned benefits
}

\author{
Luis Miguel FONSECA \\ ISEP -P. Porto and CIDEM R\&D, Porto, Portugal \\ Imf@isep.ipp.pt
}

\begin{abstract}
There is a considerable amount of interest in Industry 4.0, the so-called $4^{\text {fh }}$ industrial revolution, however, the concept is not clear in the literature. This research by performing a literature review on Industry 4.0, aims to present an overview of the several industrial revolutions with emphasis on Industry 4.0 and its underlined dimensions. Industry 4.0 is characterized by the advanced digitalization and integration of industrial manufacturing and logistics processes, and the use of internet and "smart" objects (machines and products) and merging the physical and the virtual worlds by the adoption of information and communications technology (ICT). Industry 4.0 fosters novel human and production organization systems and new organizational business models, impacting the overall value chain, society and the environment. Contributions for such new business models that can support Industry 4.0 are proposed with envisioned potential benefits such as shorter operations cycle times, quick delivery times, faster time to market of new products and services, improved quality, and product/service customization, stronger consumer involvement and loyalty. Industry 4.0 can help organizations to address new and emerging markets by a differentiation strategy, or even create new disruptive business models. However, it is still in the early stages for most companies and the digital transformation will require a strong leadership, the right human competences and to overcome several barriers, for its successful implementation. And while this will lead to a significant improvement in job creation, there will be also considerable job losses for Employees with low skill levels. Considering that in 2015, only 14\% of Small and Medium Enterprises were using internet channel and 40\% of the European Union companies still had not adopted any of the new advanced digital technologies, there is a great need to further research Industry 4.0 drivers and success factors.
\end{abstract}

Keywords: Industry 4.0, $4^{\text {th }}$ Industrial revolution, cyber-physical production systems, internet of things, smart factory.

\section{Introduction}

Due to the rapid development of communication and information technologies (ICT), we live today in an interconnected digital world characterized by increased mobility and on time access to information. Simultaneously, we must deal with a range of global issues, such as environmental protection, health improvement, and fight against poverty. Stakeholders demand that companies adopt more transparent and responsible approaches, aiming at the holistic achievement of economic growth, social progress, equity, respect, and awareness of the environment (Fonseca, et al., 2016). Organizations must address these increase demanding stakeholders and this environment has pressured Industry (the sector of the economy that produces and delivers material goods thorough mechanized and automatized process) to respond to these challenges and risks while taking advantage of the newly available opportunities.

Industry has undergone over a time, a series of "Industrial revolutions" with increasing complexity and productivity, that changed the existing paradigm. The concept of Industrial Revolution is applicable to a situation where there is a development of productive technological capacity through creativity with a relevant impact on the 
economic, environmental, and social dimensions. An Industrial Revolution can be considered as a system of macro inventions that generates events that change society in a definitive and pragmatic way, regardless of the supporting scientific basis (Mokyr, 1985).

The "1st Industrial Revolution - Power generation" started with the introduction of the power loom in 1784 and was characterized by the mechanization of the production processes and the transportation and moving of goods (Cipolla, 1965). The intensive use of electrical energy led to the "2nd Industrial Revolution- Electrification and Industrialization" (Mokyr and Strotz, 1998). With the appearance of the first programmable logic controller (PLC) in 1969 and the application of electronics, computers, and ICT (Information and Communication Technology) to automate production processes, it entered the " $3 \mathrm{~d}$ industrial revolution - Electronic automation" (Schlick et al., 2012).

There are many trends that push the industry to move into a new paradigm. These include both political, economic, social, technology, environmental and legal issues, that include, amongst the most relevant, the following ones:

- Shortened "time to market" to develop, produce and market new products and services, requiring higher and faster innovation capability;

- Increased "customization" to satisfy individual consumer demands, in a buyer' market, not anymore a seller's one, leading to higher product individualization;

- Higher "flexibility" with faster and more versatile production processes able to produce smaller lot quantities with high quality and a cost-effective way;

- "Decentralized" decision making with fewer organizational hierarchies be reduced;

- Increased resource "efficiency" by using more efficient and closed loops, regenerative, and restorative physical and economic cycles, where products and raw materials retain their physical characteristics and value as much as possible;

- Technology innovations and breakthroughs such as the internet, apps, social networks, systems engineering, smartphones, laptops, 3D-printers, artificial intelligence and machine learning, manufacturing enterprise systems (MES), etc. These new technologies provide extensive opportunities to further increasing mechanization and automation, digitalization and networking, miniaturization, decentralized development, production, and supply, with the potential to bring industry to a new change in basic assumptions, the "4th Industrial Revolution- Smart automation" (Lazi, Fettke, Feld and Hoffmann; 2014).

Industry 4.0 is a concept that was introduced to develop German economy in 2011 (Vogel-Heuser and Hess, 2016). The EU and other EU countries have also developed major Industry 4.0 initiatives (European Comission, 2015; Gobierno de Espana, 2016) and China has launched China Manufacturing 2025 (CM2025), which is in line with Industry 4.0 (European Union Chamber of Commerce in China, 2017). Industry 4.0 is based on the use of cyber-physical systems (CPS) production and heterogeneous data and knowledge integration, and its main features are: digitization, automation, optimization, customization, and adaptation of production; human machine interaction (HMI); value-added services and businesses, and automatic data exchange and communication (Posada et al., 2015).

This research comprehends a review of Industry 4.0 scientific articles entitled "Industry 4.0" in Google Scholar and of reports from major consultancy and think-thank organizations on the Industry 4.0 topic. The paper presents the views concerning Industry 4.0 concept and its implementation, potential benefits, and major challenges, and proposes 
some features for the new business models within Industry 4.0 concluding by presenting some suggestions for future research.

\section{Methodology}

A literature review was chosen as the appropriate methodological approach for the achievement of this article's objectives due to its systematic and scientific approach for the identification and evaluation of scientific works. It fosters the characterization of the stateof-art and the identification of the remaining critical or controversy issues (Fink, 2013). This research comprehends a review of Industry 4.0 scientific articles entitled "Industry 4.0" in the Google Scholar database, from the year 2011 (date in which the German Government introduced the term "Industry 4.0") to the present, and of reports from major consultancy and think-thank organizations on the Industry 4.0 topic. More than 30 articles were identified and the abstract and conclusions were reviewed to assess their relevance to this research, that aims to present an overview of the several industrial revolutions with emphasis on Industry 4.0 and its underlined dimensions.

After the analysis of the initial articles to assess their relevance and quality, the following scientific papers were considered for this research: Bagheri et al. (2014), Drath and Horch (2014), Kagermann and Helbig (2013), Hermann et al. (2016), Kube and Rinn (2014), Lasi et al. (2014), Li et al. (2015), Lu (2017), Lukac (2015), Pfeiffer (2015), Pfeiffer and Suphan (2015), Posada et al. (2015), Singer (2016), Varghese and Tandur (2014), Vogel-Heuser and Hess (2016), Zhou et al. (2015), Arnold C. (2017).

In addition, relevant reports on Industry 4.0 from major consultancy organizations, such as Boston Consulting Group, Deloitte and Mckinsey, from Governmental and EU bodies were also analyzed.

\section{Results and discussions}

\section{Industry 4.0 and the industry revolutions momentum}

Industry 4.0 is quite recent and there is still no consensus on this concept, as some authors might call it Advanced Manufacturing, Smart Manufacturing, Smart Factory, Internet of Things, Internet of Everything, or Industrial Internet, to express the same concept. However, based on the literature review, we summarize that the "4th Industrial Revolution" is characterized by the advanced digitalization and integration of industrial manufacturing and logistics processes, and the use of internet and "smart" objects (machines and products). The adoption of information and communications technology (ICT) is merging the physical and virtual worlds, in what is called the cyber-physical production systems (CPPSs) that consist of online networks of social machines, linking IT with mechanical and electronic components, that communicate between themselves via a network. Industry 4.0 creates higher value-added chains and changes the classical human and production organization systems, and the organizational business models, impacting the overall society and the environment (ACATECH, 2013). Scholars have been pointing to the need for an increased service orientation, meaning that manufacturing companies cannot be focused only on their products anymore, but rather they need adjust their value offers to a combination of both products and services, and Industry 4.0 is the backbone for such new business models (Kagermann et. al, 2013; Lasi et al. 2014). 
By applying a software analogy, this "4th Industry Revolution" is also called "Industry 4.0". Figure 1 and Table 1 show an overview of this evolution momentum of the four "Industry revolutions" and their major novelties and dimensions.

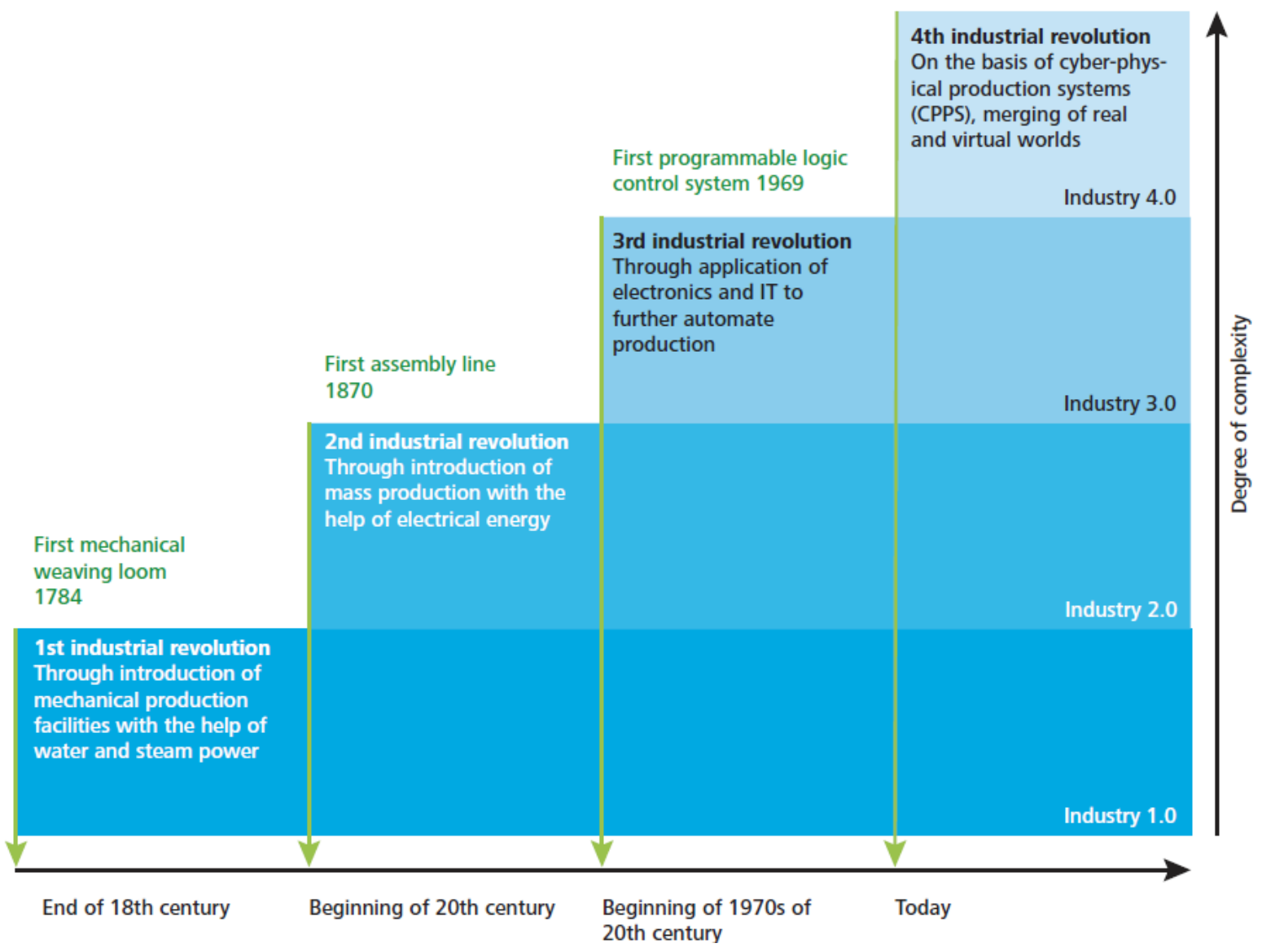

PICBE $\mid 389$

Figure 1. Industrial revolution phases (Source: Schlick et al., 2012)

Table 1. An overview of the four industrial revolutions

\begin{tabular}{|c|c|}
\hline Industry & Comments \\
\hline $\begin{array}{l}\text { First Industrial Revolution- Water- and steam- } \\
\text { powered mechanical manufacturing: } \\
\text { - Introduction of the power loom in } 1784 ; \\
\text { - Mechanization of production facilities with } \\
\text { water and steam power to increase } \\
\text { production capacity and productivity, versus } \\
\text { manual craft work; } \\
\text { - Focus on performing specific tasks faster and } \\
\text { with less variation and in transportation and } \\
\text { moving goods }\end{array}$ & $\begin{array}{l}\text { - Period: from } 1784 \text { to mid- } 19^{\text {th }} \text { century; } \\
\text { - } \quad \text { smphasis on increasing production capacity, } \\
\text { standardization, and lower costs; } \\
\text { - Directive management; } \\
\text { - People as tools. }\end{array}$ \\
\hline $\begin{array}{l}\text { Second Industrial Revolution- Industrialization: } \\
\text { - Introduction of the assembly line in } \\
\text { slaughterhouses in 1870; } \\
\text { Adaptation of electric power to industrial } \\
\text { machines, replacing steam-powered systems } \\
\text { by electric motors driving mass production } \\
\text { and increasing automation across a variety of }\end{array}$ & $\begin{array}{l}\text { - Period: from late } 19^{\text {th }} \text { century to1970s; } \\
\text { - Electric-powered mass production based on } \\
\text { the division of labor (assembly line); } \\
\text { - Emphasis on increasing production capacity, } \\
\text { - standardization, and lower costs; } \\
\text { - Directive management; }\end{array}$ \\
\hline
\end{tabular}

DOI: 10.2478/picbe-2018-0034, pp. 386-397, ISSN 2558-9652| Proceedings of the $12^{\text {th }}$ International Conference on Business Excellence 2018 


\begin{tabular}{|c|c|}
\hline industries & - $\quad$ People as resources. \\
\hline $\begin{array}{l}\text { Third Industrial Revolution- } \\
\text { automation: } \\
\text { - Development of the first programmable logic } \\
\text { controller (PLC) in 1969; increase the } \\
\text { application of electronics and ICT } \\
\text { (Information and communication } \\
\text { Technology) to automate production } \\
\text { processes; } \\
\text { Introduction of computing power to the } \\
\text { workplace replacing manual work by stand- } \\
\text { alone robotic systems }\end{array}$ & $\begin{array}{l}\text { - Period: from the } 1970 \text { s to } 2014 \text {; } \\
\text { Electronics and information technology } \\
\text { drives new levels of automation of complex } \\
\text { tasks; } \\
\text { - People as value-added resources. }\end{array}$ \\
\hline 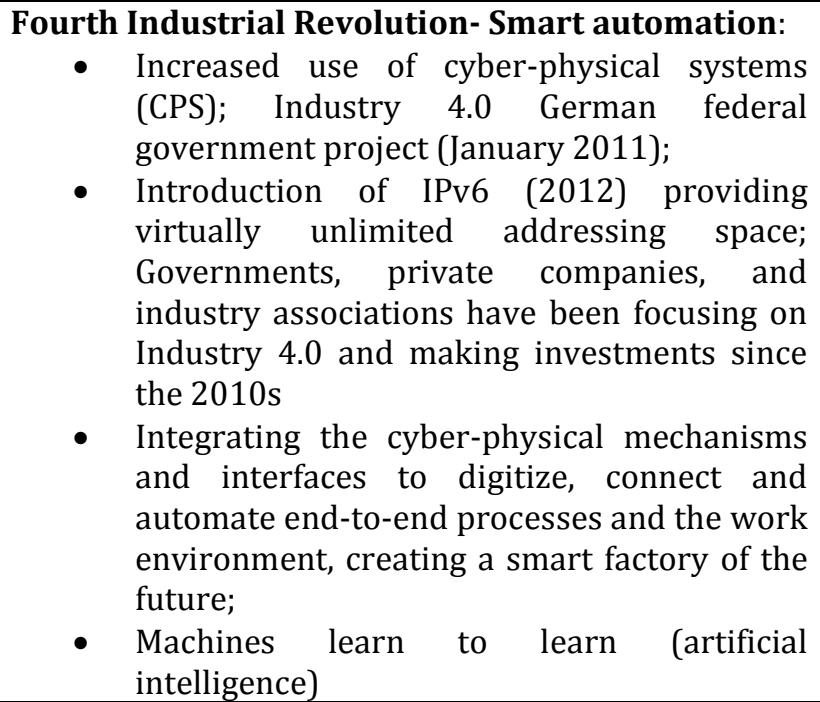 & $\begin{array}{l}\text { - Period: from 2014; } \\
\text { - Sensor technology, interconnectivity and } \\
\text { data analysis allow mass customization, } \\
\text { integration of value chains and greater } \\
\text { efficiency } \\
\text { - People as associates, emphasis on innovation } \\
\text { and development, machines perform routine } \\
\text { tasks. }\end{array}$ \\
\hline
\end{tabular}

Sources: Germany Trade \& Invest, "INDUSTRIE 4.0-Smart manufacturing for the future," July 1, 2014; National Academy of Science and Engineering, "Securing the future of German manufacturing industry: Recommendations for implementing the strategic initiative Industry 4.0," April 2013.

The digitalized production will impact manufacturing processes, outcomes, and business models, as outlined in Table 2 . A business model can be defined as a "system of interconnected and interdependent activities that determine the way the company does business with its customers, partners, and vendors" (Amit and Zott, 2012). Although there is no consensus amongst scholars on the business model definition, most agree that the business model it encompasses a system-level, comprehensive approach to explaining how firms do business, that is how value is created and captured (Zott et al., 2011). According to Casadesus-Masanell and Zhu (2013: 464) a new business model represents the "search for new logics of the firm, new ways to create and capture value for its stakeholders, and focusing, primarily, on finding new ways to generate revenues and to define value propositions for customers, suppliers, and partners".

Due to environmental dynamics, even an established and successful business model cannot be assumed as permanent given (Chesbrough, 2007, 2010; Lindgardt et al., 2009) and the "superior capacity for reinventing your business model before circumstances force you to" (Hamel and Välikangas, 2003:53) is viewed as an increasingly vital source of competitive advantage in volatile and complex environments. Industry 4.0 creates opportunities for the creation of the new business that has not yet been fully exploited 
(Bucherer et al., 2011). Figure 2 presents a systematization of Industry 4.0 environments and its major dimensions (based on the literature review) are summarized in Table 2.

Figure 2. Industry 4.0 environment (source: Deloitte, 2015)

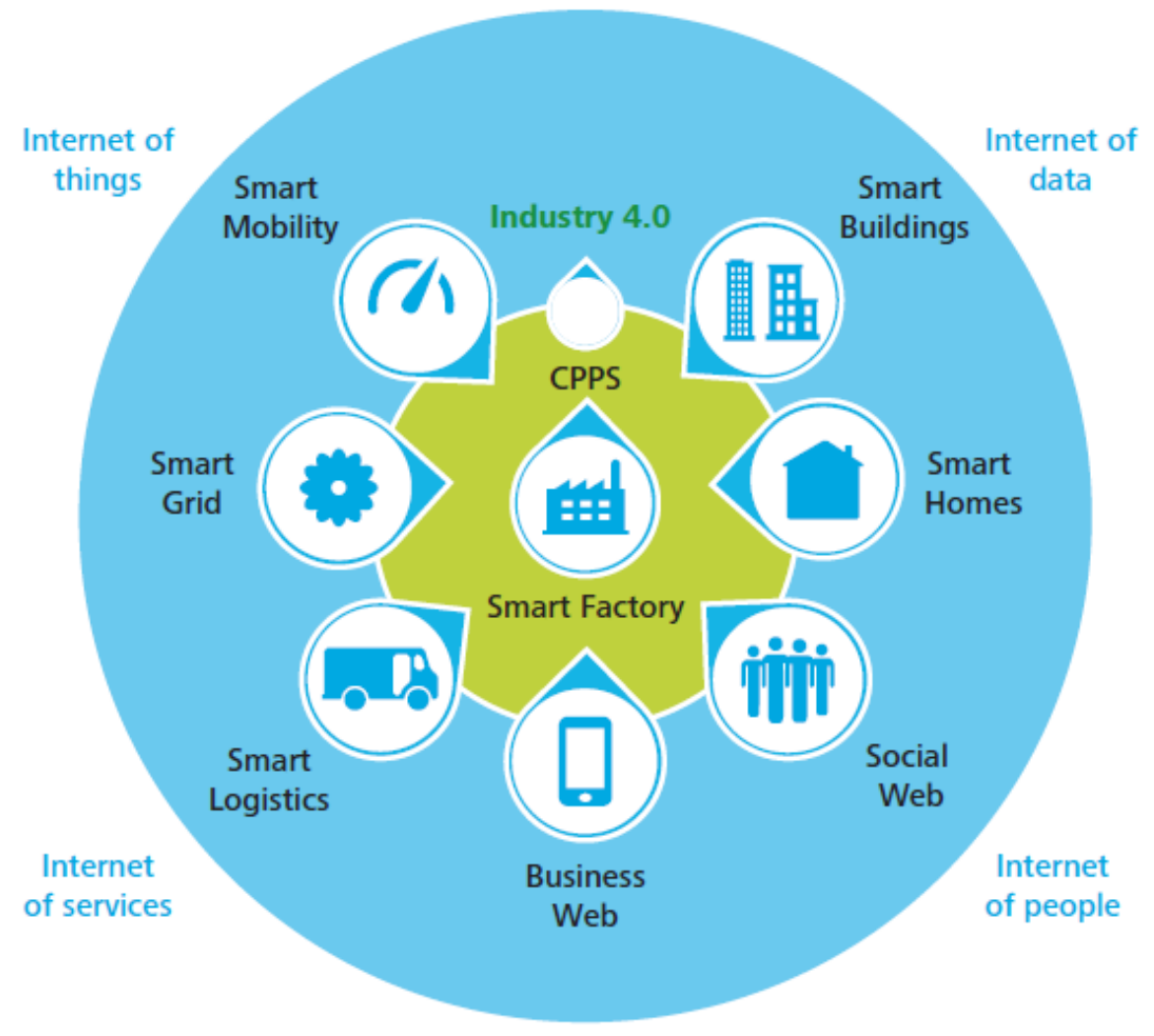

PICBE | 391

Table 2. Industry 4.0 dimensions

\begin{tabular}{|l|l|}
\hline \multicolumn{1}{|c|}{ Dimension } & \multicolumn{1}{c|}{ Impact } \\
\hline $\begin{array}{l}\text { Automation of the production process and } \\
\text { the assess to production and product data } \\
\text { through the manufacturing chain; }\end{array}$ & $\begin{array}{l}\text { It would be possible to produce in small lots } \\
\text { (up to a single unique item; } \\
\text { Prototypes or new products can be produced } \\
\text { quickly without the need for new tools or } \\
\text { machine and tools changes, change } \\
\text { minimizing the step times and costs, leading } \\
\text { to customer-supplied specifications and } \\
\text { additive manufacturing. }\end{array}$ \\
$\begin{array}{l}\text { to faster and increased innovation; } \\
\text { Estimate: Manufacturing process speed can } \\
\text { improve delivery times by 120\% and time to } \\
\text { market time by 70\%( (European }\end{array}$ \\
$\begin{array}{l}\text { Integrating product development with } \\
\text { physical and digital production: Digital } \\
\text { designs, process virtual modelling and } \\
\text { simulation and } 3 \text { printing and automated } \\
\text { assembly, can significantly reduce design, } \\
\text { production and delivering times. The } \\
\text { location of some manufacturing plants can be } \\
\text { close to the consumers, bringing industry }\end{array}$ & $\begin{array}{l}\text { Improvements in product quality and } \\
\text { reduced error rates since sensors data can be } \\
\text { used to monitor, on time, every process and } \\
\text { unit produced and detected special causes of } \\
\text { variation, rather than using control or } \\
\text { inspecting of products and processes. "Big } \\
\text { data" techniques can be used to identify and } \\
\text { solve trivial problems due to normal causes }\end{array}$ \\
\hline
\end{tabular}




\begin{tabular}{|c|c|}
\hline back to the consumer markets. & $\begin{array}{l}\text { of variation. } \\
\text { Estimate: the top } 100 \quad \text { European } \\
\text { manufacturers could save an estimated } € 160 \\
\text { billion in the costs of scrapping or reworking } \\
\text { defective products if they could eliminate all } \\
\text { defects (European Commission, 2015). }\end{array}$ \\
\hline $\begin{array}{l}\text { - The use of advanced analytics will improve } \\
\text { predictive maintenance, avoid equipment } \\
\text { failures and downtime. In some factories, } \\
\text { there will be no need for human workers in } \\
\text { the assembly lines not requiring light or heat. } \\
\text { Human workers can be used for tasks where } \\
\text { they are essential, such as innovation, } \\
\text { process and product improvement and } \\
\text { quality assurance. }\end{array}$ & $\begin{array}{l}\text { - Downtime can be decreased by } 50 \% \text { and } \\
\text { increase production by } 20 \% \text { (European } \\
\text { Commission, 2015). }\end{array}$ \\
\hline $\begin{array}{l}\text { - Industry } 4.0 \text { will also provoke changes in } \\
\text { business models with emphasis on } \\
\text { differentiation by innovation and speed, } \\
\text { customization, and better quality. Innovation } \\
\text { cycles can be shortened, productivity raised } \\
\text { and quality improved. } \\
\text { - The available data can be used to create and } \\
\text { deliver 'smart' products } \\
\text { - New business models based on selling } \\
\text { services not products ("servitisation") can } \\
\text { generate new business opportunities higher } \\
\text { revenues and profits. }\end{array}$ & $\begin{array}{l}\text { Employees with low skill levels risk } \\
\text { becoming replaceable unless they are } \\
\text { retrained, but those with the right } \\
\text { competencies (creativity, decision-making } \\
\text { skills, and technical and ICT expertise) will } \\
\text { have more autonomy and interesting work. }\end{array}$ \\
\hline
\end{tabular}

Source: adapted from Davies, 2015 (R. EPRS | European Parliamentary Research Service. Members'

Research Service PE 568.337).

Industry 4.0 is expected to be a source of major economic, environmental, and social value creation, however, there are some challenges that must be overcome (Davies, 2015):

- The need for considered investments in automation and ICT;

- The adoption of new collaborative business models including new possible partners such as telecoms and internet service providers;

- The ownership, confidentially and security of the large amount of collected needs to be cleared and assured, to ensure trust and data protection;

- There are also several legal issues such as employee supervision, product liability and intellectual property that must be tackled.

\section{New Business Models and envisioned potential benefits of Industry 4.0}

The organizations that adopt the Industry 4.0 can expect to significantly improve their present competitive position, increasing value creation and minimizing risks. The adoption of more efficient and faster production systems and of innovative technologies will allow shorter operations, delivery times and faster time to market of new products and services. Additionally, they can reduce process and product variation, assuring higher consistency and quality, while involving the consumer in a more proactive and intense way. They can address new and emerging markets by a differentiation strategy, or even create new disruptive business models, such as those of Uber, Booking, Airbnb or Alibaba. 
The EU has been actively advocating for Industry 4.0 and Europe Digital Transformation, accordingly to the Strategic Policy Forum on Digital Entrepreneurship final "Digital Transformation of European Industry and Enterprises" (2015), the benefits for Europe of Digital Transformation can be summarized as follows:

1. Companies applying the new accelerating technologies are performing 10 times better than their competitors;

2. A fully realized Digital Single market can generate a 6\% GDP (Gross domestic product) increase, create more 3,8 million jobs, and reduce the costs of public administration by 15 to $20 \%$;

3. The internet economy has the potential to create 1.5 million new jobs in the European Union;

4. Bid data technology and services are expected to represent USD 16.5 billion with a compound annual growth rate of $40 \%$;

5. Companies using Big data technology and services can become5 to $6 \%$ more productive;

6. European manufacturing can increase 15 to $20 \%$ by 2030 if digitalized;

7. E-learning market will growth by a factor of 15 over the next 10 years and reach $30 \%$ of the education market;

8. However, in 2015, only 14\% of Small and Medium Enterprises were using internet channel and $40 \%$ of the European Union companies still had not adopted any of the new advanced digital technologies;

9. Technologies advances could threaten $54 \%$ of the European Union workforce over the coming decades, but in Germany SMEs for every job destroyed, 2.6 new jobs were created;

10. Finally, Industry 4.0 and Digital transformation will require: a strong leadership and the adoption of collaboration stakeholder models and networks; trust about data personal data security and fraud avoidance; to address the concern about potential loss of revenues and control if commercial opportunity moves from the business itself to some other organization that controls the data platform the business is planning to use; the availability of better and more digital skills and support; better governmental policies and regulatory rules and regulations.

Figure 3 presents the results of a research amongst 300 industry experts from a wide range of industries in Japan, USA, and Germany, that identified the major barriers both manufacturers with no/limited progress in Industry 4.0, and those more advanced ones, face to successful adopt Industry 4.0 (Mckinsey, 2016): 
Top 5 barriers mentioned by manufacturers with no/limited progress in Industry 4.0

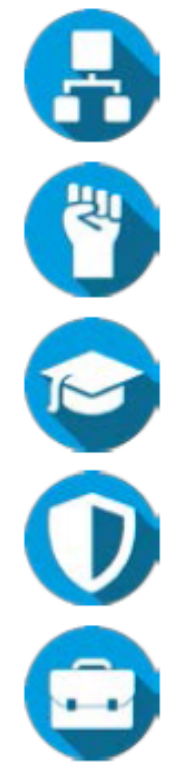

Difficulty in coordinating actions across different organizational units

Lack of courage to push through radical transformation

Lack of necessary talent, e.g., data scientists

Concerns about cybersecurity when working with third-party providers

Lack of a clear business case that justifies investments in the underlying IT architecture
Additional top barriers mentioned by more advanced manufacturers

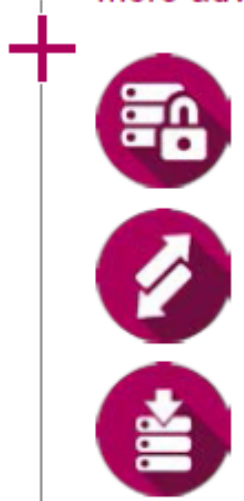

Concerns about data ownership when working with third-party providers

Uncertainty about invs. outsourcing and lack of knowledge about providers

Challenges with integrating data from disparate sources in order to enable Industry 4.0 applications

PICBE | 394

SOURCE: McKinsey Industry 4.0 Global Expert Survey 2016

Figure 3. major barriers to Industry 4.0 implementation /source: Mckinsey, 2016)

Finally, a research with google trends for the keywords "digital transformation" (blue trend), "smart automation" (red trend) and "industry 4.0" (yellow trend), show that the most popular internet keyword is "digital transformation" followed by "industry 4.0" and "smart automation" (Figure 4). However, if the keyword "big data" is added, this one clearly overpasses all the others (Figure 5).
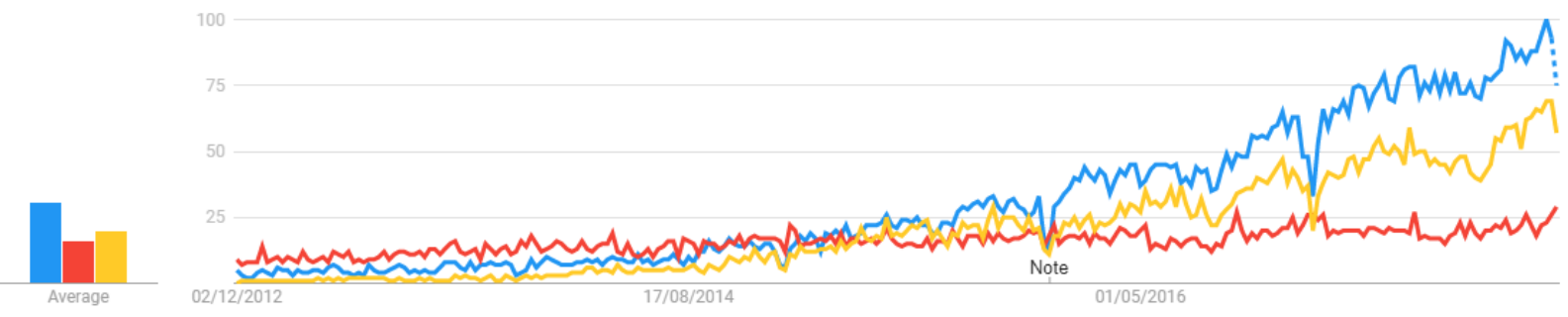

Figure 4. Google trends data for the last 5 years, for 3 keywords, accessed 2017.11.29 


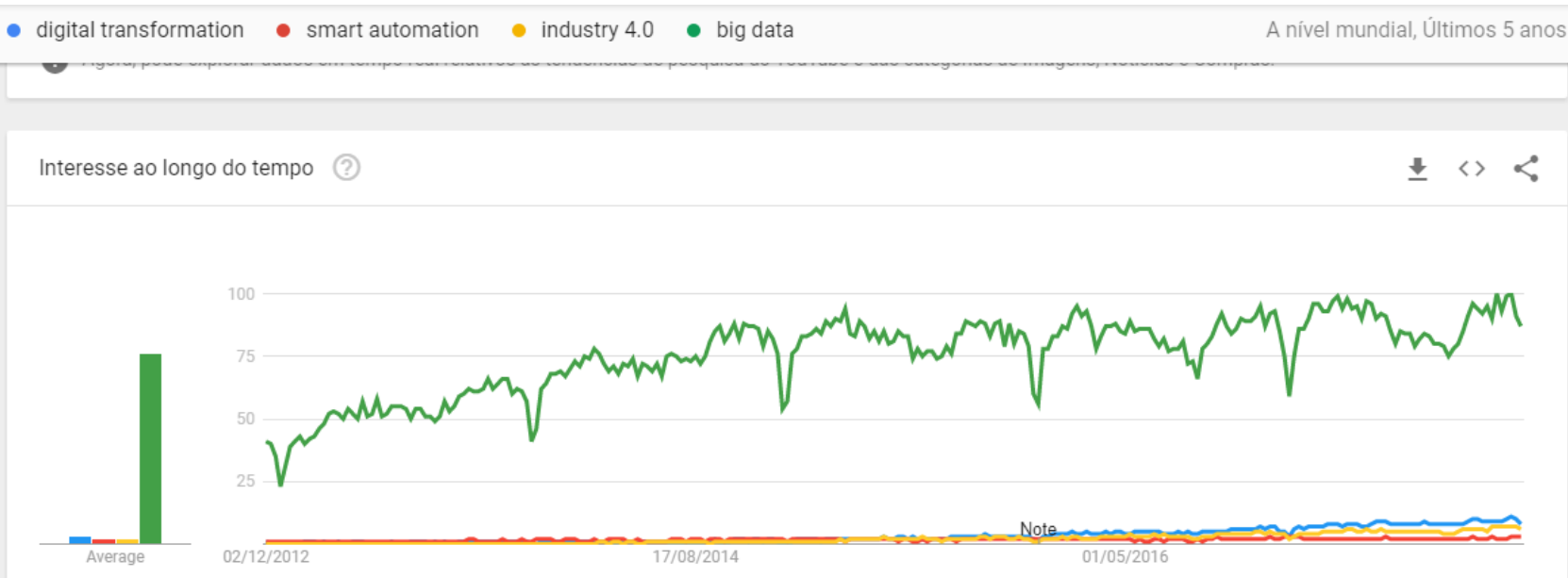

Figure 5. Google trends data for the last 5 years, for 4 keywords, accessed 2017.11.29

\section{Conclusion}

To sum up, Industry 4.0 implies the digitization of manufacturing via connected networks of humans and robots interacting and working together and promotes information sharing and analysis along the full global value chains. The aim is that companies by effectively implementing Industry 4.0 significantly improve their competitive position, increasing value creation and minimizing risks, with the adoption of more efficient and faster production systems and innovative technologies. Amongst the main envisaged benefits are shorter operations cycle times, quick delivery times, faster time to market of new products and services, improved quality, and product/service customization, while involving the consumer in a more proactive and intense way. They can address new and emerging markets by a differentiation strategy, or even create new disruptive business models.

However, Industry 4.0 is still in the early stages for most companies and the digital transformation will require a strong leadership, the right human competences and to overcome the several barriers identified for its successful implementation. Although the literature indicates that the adoption of Industry 4.0 improves companies' performance, there are still many organizations that do not apply and don't feel comfortable about doing it. This leads to opportunities to further investigate the areas where companies should prioritize the adoption of Industry 4.0 and to consider not only the technical aspects, but also the management, organizational and human dimensions, including what types of novel business models and people skills are required for the future, and what are the change processes to make it happen.

\section{Acknowledgements}

CIDEM, R\&D unit is funded by the FCT - Portuguese Foundation for the Development of Science and Technology, Ministry of Science, Technology, and Higher Education, under the Project UID/EMS/0615/2016.

\section{References}

ACATTECH (2013). Recommendations for implementing the strategic initiative Industrie 4.0, German National Academy of Science and Engineering. 
Amit, R. and Zott, C. (2012). Creating value through business model innovation. MIT Sloan Management Review, 53(3), 41-49.

Arnold, Christian. (2017). The Industrial Internet of Things from a Management Perspective: A Systematic Review of Current Literature. Journal of Emerging Trends in Marketing and Management, 1 (1), 8-21.

Bagheri, B., Yang, S., Kao, H.A. and Lee, J. (2015). Cyber-physical systems architecture for self-aware machines in Industry 4.0 environment. IFAC-PapersOnLine 48 (2015) 1622-1627.

Bucherer, E., Eisert, U. and Gassmann, G. (2012). Towards systematic business model innovation: Lessons from product innovation management. Creativity and Innovation Management, 21(2), 183-198.

Casadesus-Masanell, R. and Zhu, F. (2013). Business model innovation and competitive imitation. Strategic Management Journal, 34(4), 464-482.

Chesbrough, H (2006). Open Business Models: How to Thrive in the Innovation Landscape. Boston, MA: Harvard Business School Press.

Chesbrough, H. (2007). Business model innovation: It's not just about technology anymore. Strategy and Leadership, 35(6), 12-17.

Cippola, C.M. (1965). Guns, Sails, and Empires: Technological Innovation and the Early Phases of European Expansion, 1400- 1700. Sunflower University Press. ISBN-10: 089745071X.

Davies (2015) (R. EPRS | European Parliamentary Research Service. Members' Research Service PE 568.337)

European Commission. (2015). Digital transformation of European industry and enterprises, Strategic Policy Forum on Digital Entrepreneurship.

Drath, R. and Horch, H. (2014). Industrie 4.0: hit or hype? [industry forum], IEEE Industrial Electronic Magazine, 8(2), 56-58.

European Union Chamber of Commerce in China (2017). China manufacturing 2025: Putting industrial policy ahead of market forces. http://.docs.dpaq.de/ 12007european _ chamber_cm2025-en.pdf .

Fonseca, L., Ramos, A., Rosa, A., Braga, A.C., Sampaio, P. (2016). Stakeholders satisfaction and sustainable success. International Journal of Industrial and Systems Engineering, 2 (2), 144-157.

Gobierno de España (2016). La transformación digital de la industria española, Industria conectada 4.0. http://www.industriaconectada40.gob.es/Paginas/index.aspx, accessed 2017.10.25.

Hamel, G and L Välikangas (2003). The quest for resilience. Harvard Business Review, 81(9), 52-63.

Hermann, M., Pentek, T. and Otto, B. (2016). Design principles for Industrie 4.0 scenarios, in: 2016 49th Hawaii International Conference on System Sciences (HICSS), IEEE, 3928-3937.

Industry 4.0: the future of productivity and growth in manufacturing industries. (2015). Boston Consulting Group.

Kagermann, WW.H and, Helbig, J. (2013). Recommendations for implementing the strategic initiative Industrie 4.0- Available from: http://www. acatech.de/fileadmin/user upload/Baumstruktur_nach_Website/Acatech/root/de/Material_fuer _ Sonderseiten/Industrie _ 4.0/Final_report _ Industrie _ 4. $0_{-}$accessible.pdf . 
Kube, G. and Rinn, T. (2014). Industry 4.0-the next revolution in the industrial sector, ZKG International. 67 (11), 30-32.

Lasi, H., Fettke, P., Kemper, H-G, Feld, T., and Hoffmann, M. (2014). Industry 4.0. Business \& Information Systems Engineering: The International Journal of WIRTSCHAFTSINFORMATIK, 6 (4), 239-242. DOI 10.1007/s12599-014-0334-4.

Li, X. Li, D., Wan, J., Vasilakos, A.V., Lai, C.F. and Wang, S. (2015). A review of industrial wireless networks in the context of Industry 4.0, Wireless Networks, 23(1), 1-19.

Lindgardt, Z, M Reeves, G Stalk and M Deimler (2009). Business Model Innovation: When the Game Gets Tough, Change the Game. The Boston Consulting Group.

Lu Y., 2017.Industry 4.0: A survey on technologies, applications and open research issues . Journal of Industrial Information Integration, 6, 1-10.

Lukac, D. (2015). The fourth ICT-based industrial revolution" Industry 4.0" HMI and the case of CAE/CAD innovation with EPLAN P8, in: 23rd Telecommunications Forum Telfor (TELFOR), IEEE, pp. 835-838.

Mckinsey\&Company, (2016). Industry 4.0 after the initial hype, Mckinsey Digital.

Mokyr, J. (1985): The New Economic History and The Industrial Revolution, Rowan \& Littlefield Publishers Inc., USA.

Mokyr, J. and Strotz, R. (1998). The Second Industrial Revolution. Northwestern University, p. 1870-1914.

Pfeiffer, S., 2016. Robots, Industry 4.0 and humans, or why assembly work is more than routine work, Societies, 6 2), 16.

Pfeiffer, S. and Suphan, A. (2015). The labouring capacity index: living labouring capacity and experience as resources on the road to Industry 4.0. Available online: (accessed 30.01.16) http://www.sabine-pfeiffer.de/files/downloads/ 2015-Pfeiffer-SuphanEN.pdf .

Posada, J. Toro, C., Barandiaran, I., Oyarzun, D., Stricker, D., de Amicis, R. and Vallarino, I. (2015). Visual computing as a key enabling technology for industrie 4.0 and industrial internet. IEEE Computer Graphics and Applications, 35 (2), 26-40.

Schlick, J., Stephan, P. and Zuhkle, D. (2012). Produktion 2020. Auf dem Weg zur 4.0. industriellen Revolution. IM - Fachzeitschrift fur Information Management und Consulting. August 2012.

Singer, P. 2016. Are you ready for Industry 4.0? Solid State Technology. 58 (8), 2.

Varghese, A., Tandur, D. 2014. Wireless requirements and challenges in industry 4.0, in: 2014 International Conference on Contemporary Computing and Informat- ics (IC3I), IEEE, 634-638.

Vogel-Heuser, B., Hess, D. (2016). Guest editorial Industry 4.0-prerequisites and visions, IEEE Transactions on Automation Science and Engineering, 13(2), 411-413.

Zott, C., Amit, R. and Massa, L. (2011). The business model: recent developments and future research. Journal of Management. 37(4), 1019-1042.

Zhou, K., Liu, T. and Zhou, L. (2015). Industry 4.0: towards future industrial opportunities and challenges, in: 12th International Conference on Fuzzy Systems and Knowledge Discovery (FSKD), IEEE, 2147-2152. 